\title{
Changes in the Physicochemical Properties of Kashkaval of Pindos Cheese Produced with Different Salting Methods during Ripening
}

\author{
Eleni C. Pappa ${ }^{1}$, Efthymia Kondyli ${ }^{1}$, Loulouda Bosnea ${ }^{1} \&$ Marios Mataragas ${ }^{1}$ \\ ${ }^{1}$ Hellenic Agricultural Organization-DEMETER, Institute of Technology of Agricultural Products, Dairy \\ Research Department, Katsikas 45221, Ioannina, Greece \\ Correspondence: Eleni C. Pappa Hellenic Agricultural Organization-DEMETER, Institute of Technology of \\ Agricultural Products, Dairy Research Department, Katsikas 45221, Ioannina, Greece. Tel: 30-265-109-4780. \\ E-mail: pappa.eleni@yahoo.gr
}

Received: August 4, 2020

Accepted: August 29, $2020 \quad$ Online Published: October 6, 2020

doi:10.5539/jfr.v9n6p13

URL: https://doi.org/10.5539/jfr.v9n6p13

\begin{abstract}
Kashkaval of Pindos cheeses were produced either with sheep (100\%) or mixture of sheep (90\%) - goat (10\%) milk. Sheep milk cheeses were manufactured either by dry salting or by immersion in $18 \% \mathrm{w} / \mathrm{w}$ salt $(\mathrm{NaCl})$ brine. Cheeses made with the mixture of sheep- goat milk were directly immersed in brine of $15 \%$ or $18 \% \mathrm{w} / \mathrm{w} \mathrm{NaCl}$ concentration. These are common practices of cheese salting used by the traditional cheese-makers. The physicochemical characteristics of all cheeses were monitored during a ripening period of 3-months. The results have shown that the physicochemical characteristics of both cheeses were not affected by the different salting methods. Therefore, Kashkaval of Pindos cheese can be salted either with dry salt or with immersion in brine, without altering their main composition and organoleptic characteristics. Furthermore, some historical data about Kashkaval of Pindos cheese are included.
\end{abstract}

Keywords: traditional, cheese, Kashkaval of Pindos, salting

\section{Introduction}

The endurance of rural human population in less favoured areas assures the safeguard and survival of biodiversity and leads to the manufacture of traditional products. A traditional product is a result of several factors such as raw material, transformation process and sensory characteristics (Scintu \& Piredda, 2007). In this respect, it is of major importance to support the maintenance of the production of local cheeses. Greece has a wide variety of artisanal cheeses, each one with its own distinctive texture, flavour and aroma; characteristics that clearly reflect their terroir of production. Kashkaval of Pindos is a traditional paste filata cheese produced seasonally in the mountains of Pindos as a farmhouse product. Nowadays, there is an increasing demand by consumers for this local cheese. However, in order to produce a cheese with consistent physicochemical characteristics in respect to its traditional character, it is necessary to study the various technological parameters that are commonly used by different cheesemakers, on farm level. It is known that in traditional production of this type of cheese, salt can be added by either dry salting or direct immersion of cheese in brine (Pejic, 1956; Scott, 1981; Kindstedt et al., 2004).

The traditional cheese-making technology of Kashkaval cheese has been recorded since the beginning of the previous century (Dimitriadis, 1900; Liambeis, 1900; Polychroniadis, 1912) and the biochemical characteristics of the artisanal cheese have been studied before (Pappa et al., 2019; Samelis et al., 2019). The aim of the present work was a) to study the effect of the salting methods that are commonly used in its manufacture by the different cheese-makers and b) to provide some historical data regarding the Kashkaval of Pindos cheese. Therefore, in the present study, the physicochemical characteristics of Kashkaval of Pindos cheese manufactured with sheep milk and salted with two different methods: dry salting or immersion in brine $(18 \% \mathrm{w} / \mathrm{w})$, at different ripening dates were studied. Moreover, the physico-chemical parameters of Kashkaval of Pindos cheese manufactured with mixture of sheep (90\%)-goat (10\%) milk and salted by direct immersion in brine with concentration $15 \%$ or $18 \% \mathrm{w} / \mathrm{w}$ were assessed during ripening. 


\section{Materials and Methods}

\subsection{Cheesemaking}

Kashkaval of Pindos cheeses were produced at the pilot plant of Dairy Research Department, Institute of Technology of Agricultural Products, using 100\% sheep (Sh-K) or mixture of $90 \%$ sheep-10\% goat (mix-K) milk following the procedure as described elsewhere (Pappa et al., 2020) and presented in Table 1.

Table 1. Protocol of Kashkaval of Pindos manufacture

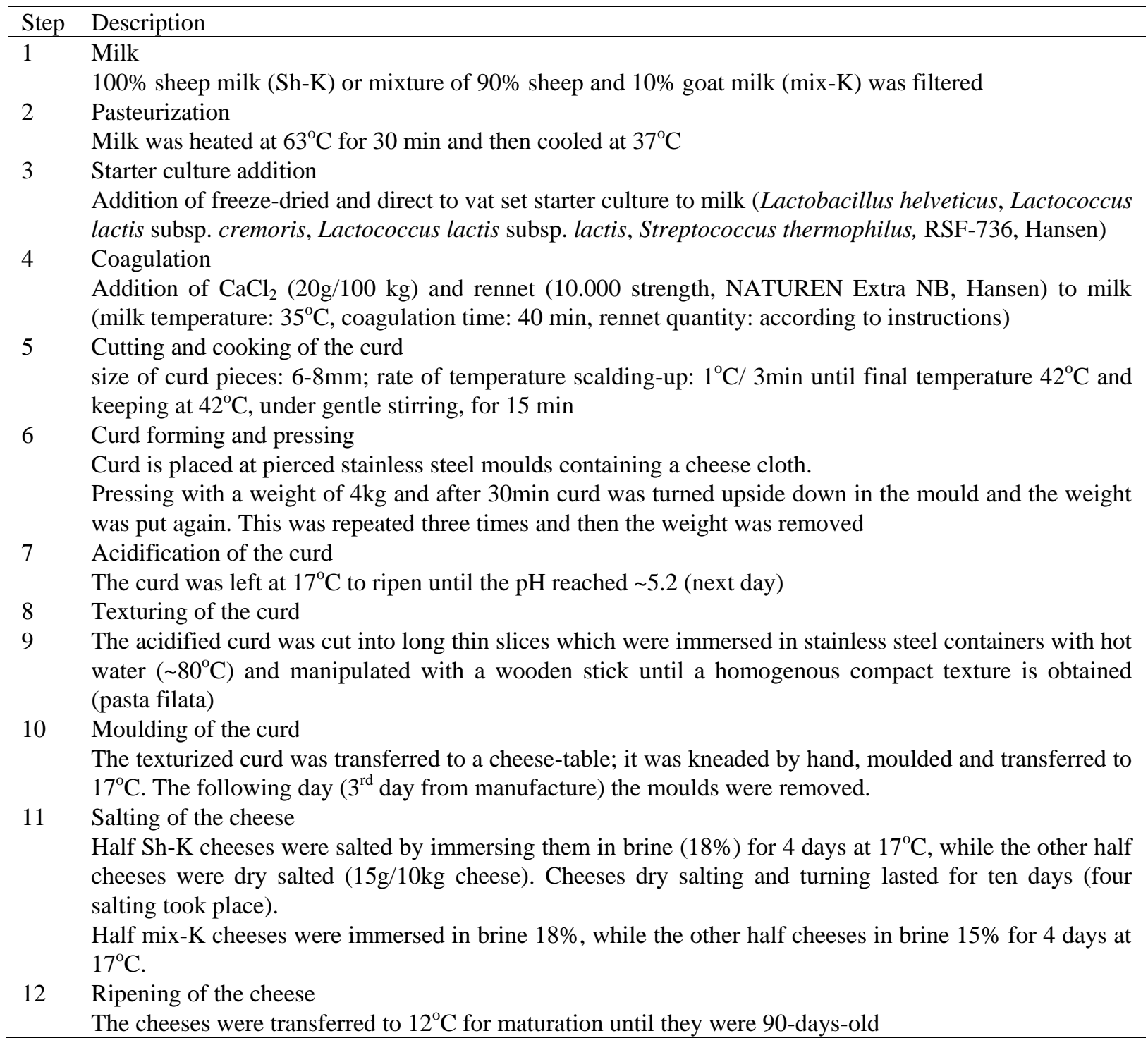

\subsection{Analysis of Cheese}

The milk for the cheesemaking was analyzed for physicochemical parameters, i.e. fat, protein, lactose, total solid by Milko-Scan, model 6000 (Foss Electric, Hillerød, Denmark). Milk pH was measured directly with a pH meter (Micro pH 2002; Crison, Barcelona, Spain). Microbiological evaluation was carried out by assessing the total viable counts (TVC) using the Bactoscan FC (Foss Electric, Hillerød, Denmark).

Cheese samples were examined for $\mathrm{pH}$ electrometrically (Micro pH 2002; Crison, Barcelona, Spain) and were analyzed for their fat according to the Gerber-Van Gulik method (Schneider, 1954), salt according to the modified Volhard method (Kosikowski, 1982) and moisture content by drying to constant weight at $102 \pm 1^{\circ} \mathrm{C}$ (International Dairy Federation, 1982). The fat-in-dry-matter (FDM) content was calculated by the formula: $\mathrm{FDM} \%=$ fat $\%$ x 100/100- moisture $\%$.

Cheeses were, also, assessed organoleptically by five trained panel members who were permanent staff of the 
Dairy Research Department; all of them well experienced and familiar with pasta filata cheeses.

\section{Results and Discussion}

\subsection{Effect of the Different Salting Methods on the Physicochemical Characteristics of Kashkaval of Pindos} Cheese

The composition of the milk used for the manufacture of Kashkaval of Pindos cheese was fat 5.50\%, protein $4.76 \%$, lactose $4.99 \%$, total solids $16.09 \%$ and its $\mathrm{pH}$ was 6.74 for the sheep milk (Sh-K) and $6.06 \%, 4.72 \%$, $4.86 \%, 16.46 \%$ and 6.74 respectively for the mixture of $90 \%$ sheep and $10 \%$ goat milk (mix-K). The total viable counts of sheep milk were $4.79 \mathrm{log} \mathrm{cfu} / \mathrm{mL}$ and of mixture of sheep-goat $5.88 \mathrm{log} \mathrm{cfu} / \mathrm{mL}$. The above results show that the milk used for the manufacture of cheeses was of good quality.

The physicochemical characteristics of Sh-K cheeses are presented in Figure 1 (a-d) and of mix-K cheeses in Figure 2 (a-d). The $\mathrm{pH}$, moisture, fat and salt content of Kashkaval of Pindos cheese made with 100\%sheep milk exhibited the same trend regardless the way of salting (i,e. dry salting or immersion in brine, at all sampling days (Figure 1 a-d). Also, cheeses manufactured using a mixture of 90\%sheep -10\%goat milk and salted with immersion in brine $15 \%$ or $18 \%$ showed similar $\mathrm{pH}$, moisture, fat and salt content, at all sampling days (Figure 2 a-d). The results have shown that in general, at 30 days of ripening the physicochemical characteristics of Kashkaval of Pindos cheeses, regardless the type of salting method used, reached equilibrium. The physicochemical characteristics found in this study were in accordance with the data found by others (Kindsted et al., 2004; Alichanidis, \& Polychroniadou, 2008; Pappa et al., 2019; Pappa et al., 2020) for pasta filata and Kashkaval cheeses.

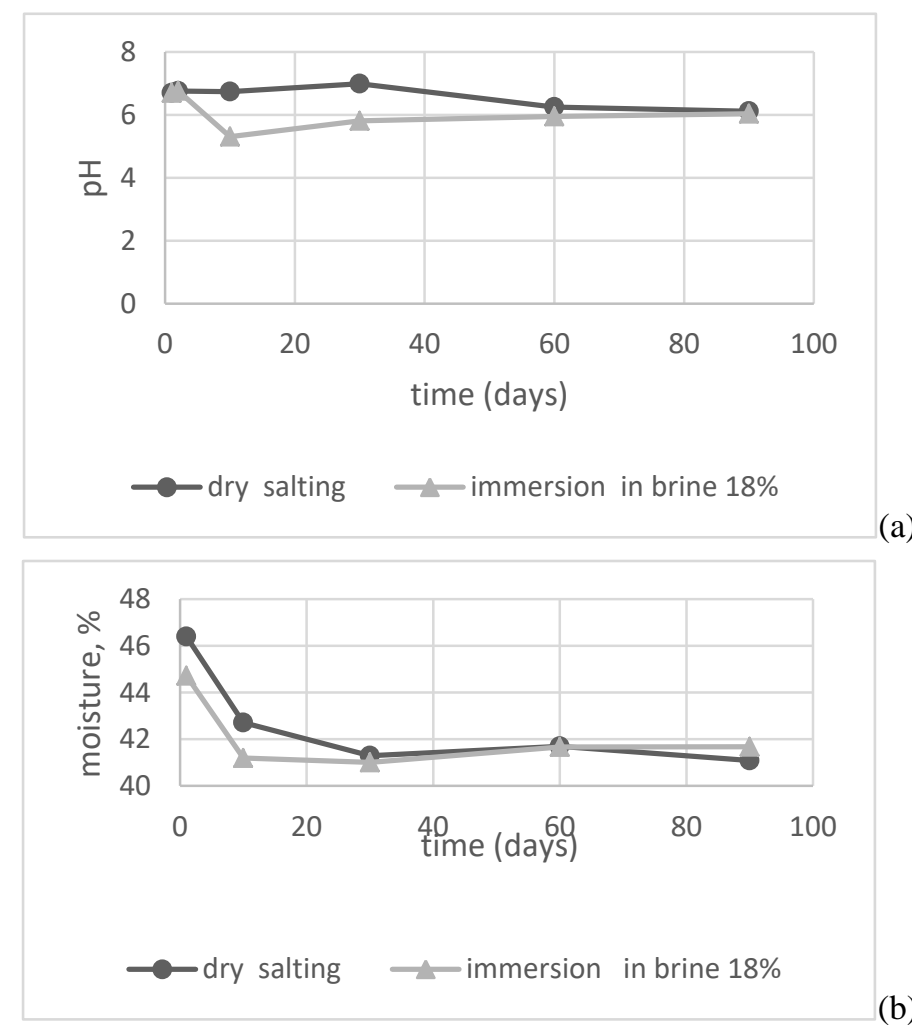




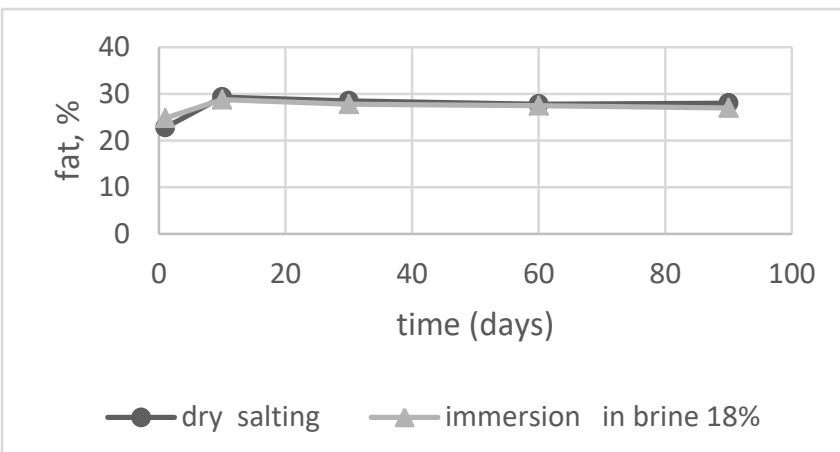

(c)

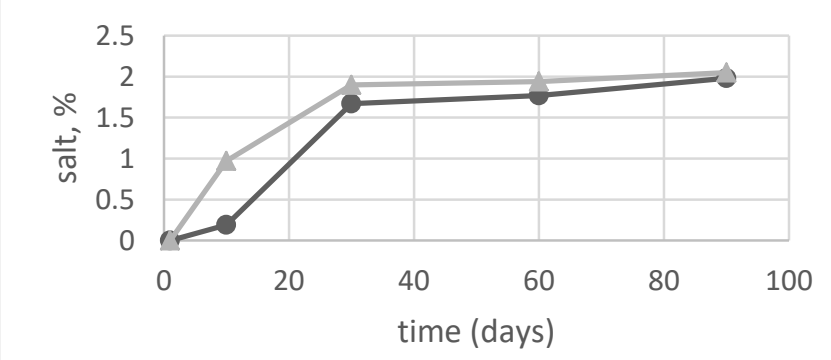

$\longrightarrow$ dry salting —immersion in brine $18 \%$

Figure 1. Effect of type of salting on the $\mathrm{pH}$ (a), moisture (b), fat (c) and salt content (d) of Kashkaval of Pindos cheese made with $100 \%$ sheep milk

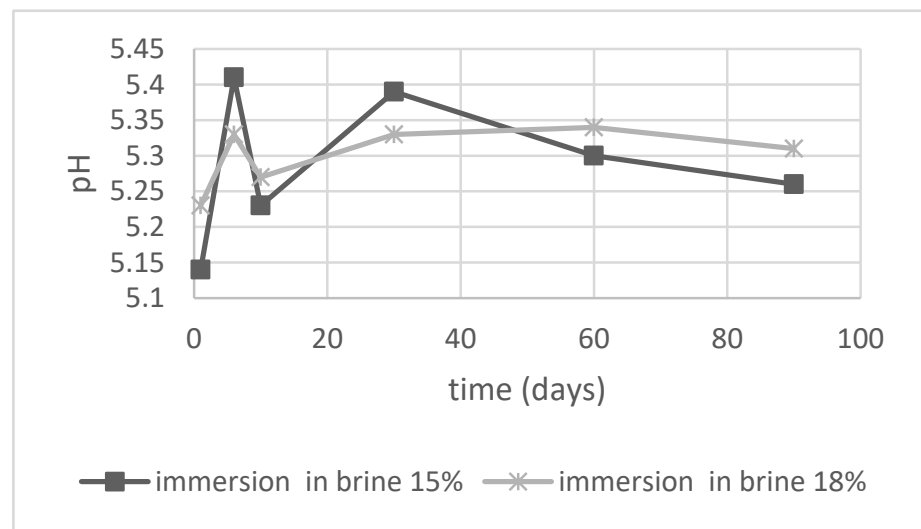

(a)

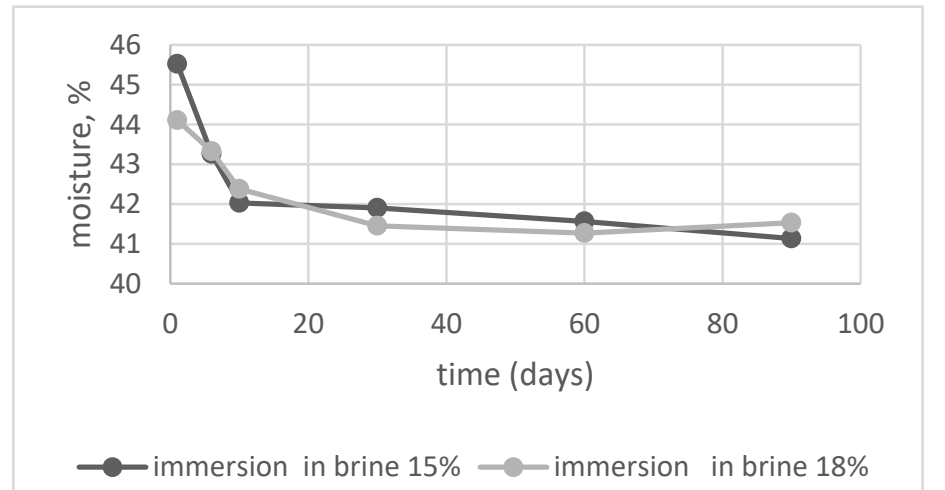

(b) 


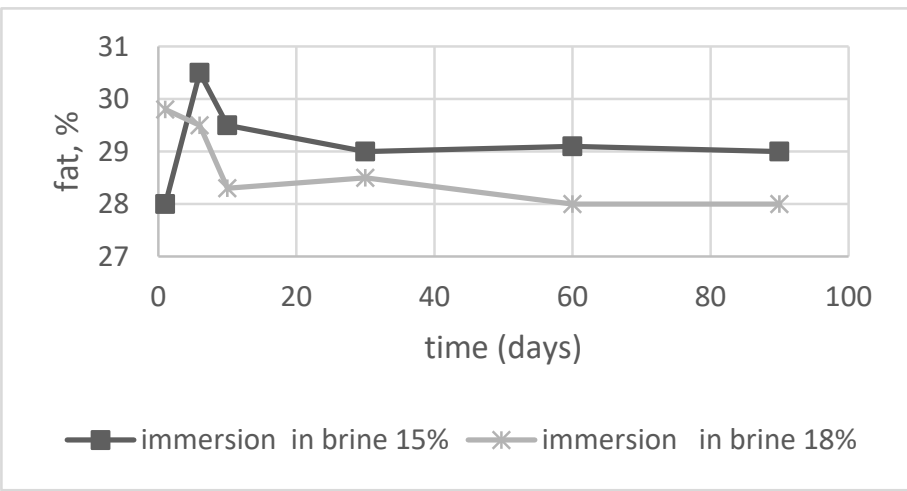

(c)

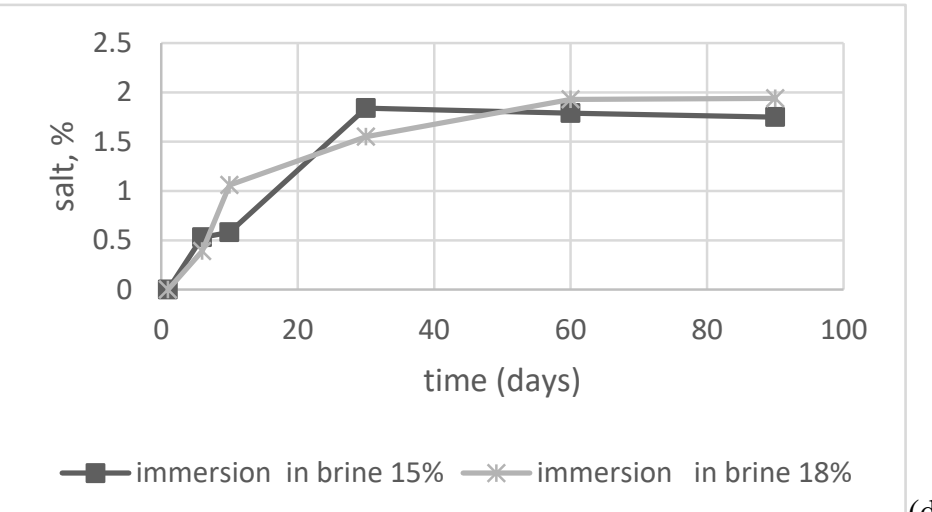

(d)

Figure 2. Effect of brine concentration on the $\mathrm{pH}$ (a), moisture (b), fat (c) and salt content (d) of Kashkaval of Pindos cheese made with mixture of $90 \%$ sheep -10\%goat milk

Initially, there was a decrease in the $\mathrm{pH}$ values of the cheese due to the accumulation of lactic acid produced by the action of microorganisms to the residual lactose. Then, from day 1 to the end of salting there was an increase in the $\mathrm{pH}$ values and that could be attributed to the buffering effect of milk salts transferred in the cheese (Perna et al., 2014). Also, plasticization of the curd had a major influence on the composition, structure and ripening of Kashkaval cheese, as the cheese mass is washed to some extent, resulted in an increase of the $\mathrm{pH}$ values (Gobbetti et al., 2002). An increase in the $\mathrm{pH}$ values were also observed in Kashkaval cheese (Omar \& El-Zayat, 1986).

The moisture content decreased until the end of salting time, probably due to the syneresis of cheeses (Pappa et al., 2006). The dry matter content (i.e. DM\%= 100-moisture\%) of all produced cheeses over 60 days-old ranged from $58.31-58.92 \%$ (data not shown).

Fat content of cheeses increased from day 1 until the end of salting. This trend is due to loss of moisture during the early stages of ripening. The FDM content of over 60-day cheeses regardless the type of milk or the salting method ranged from 47.14-49.79\%. All Kashkaval of Pindos cheeses of this study fulfilled the requirements of regulation No 1225/90 of European Economic Community, i.e. fat-in-dry matter $>45 \%$ and dry matter $>58 \%$.

The $\mathrm{NaCl}$ percentage of the Sh-K cheeses salted with the different methods, i.e. dry salting or immersion in $18 \%$ brine was similar (Figure 1d). Also, the salt content of mix-K cheeses salted with immersion in brine $18 \%$ or $15 \%$ did not differ (Figure $2 \mathrm{~d}$ ), especially at the end of ripening (90 days). Therefore, the different salting methods did not affect the salt content of the Sh-K and mix-K cheeses.

According to the Greek Codex Alimentarius (2014) Kashkaval of Pindos cheese can be sold in the market after 90 days of ripening. At that age, the organoleptic evaluation has shown that all cheeses in this study were very much appreciated by the five trained panel members. Their appearance was fairly yellow, with a smooth and thin rind and with occasionally technological slits. The texture was firm and elastic and the flavour was mild, with piquant, fruity and buttery notes. Panellists did not observe any difference regarding the salty taste of the cheeses produced with the different salting methods. No quality defects were found such as red or dirty white rind, gas holes etc as described by Caric (1993) for Kashkaval cheese and no goaty flavor was reported in the mix-K 
cheeses.

\subsection{Historical Data of Kashkaval of Pindos Cheese}

Greece is a mountainous country and Pindos is its biggest mountain range with many picturesque villages such as Metsovo, Samarina, Syrako etc around it, with a long history in sheep and goat breeding and cheese making. The main agricultural activity of the nomadic and non-nomadic populations that lived for many years in the mountains of Pindos was sheep and goat breeding so as to provide milk, meat and wool for their families. In order to preserve milk for a longer time, they used to manufacture cheeses. Kashkaval of Pindos has been one of the most traditional and popular cheese during the centuries of the prevail of the Ottoman Empire in Greece. As this cheese belongs to pasta-filata group, its manufacture consists of two stages, the acidification of the curd after its production and the texturizing of the acidified curd with heating, kneading and stretching by soaking in hot water or in brine. Its manufacture was very popular especially during the hot summer. The coagulation and drainage of the curd was made in the mountains of Pindos to prolong the shelf-life of milk and then the drained cheese curds were gathered together and transported to the lowlands for further processing. Moreover, raw milk or milk with an increased acidity could be used for its production as during the texturizing of the acidified curd in hot water or brine $\left(\approx 80^{\circ} \mathrm{C}\right)$ a partial elimination or control of the pathogenic microflora could be achieved.

At that time, living conditions in Greece were very difficult, including unbearable taxes, robberies, killings etc. Residents of Pindos's villages were extremely familiar with the mountain trails and since the borders among the countries were not clearly demarcated, they managed to develop trade all over the Balkan Peninsula by travelling a lot with their horses, carrying various products such as wheat, oil, wool and cheese and selling them in markets. Furthermore, during the $18^{\text {th }}$ century, population from the regions of Epirus and West Macedonia emigrated due to persecution or economic reasons to places such as Serbia, Austria-Hungary, Eastern Rumelia and others, exchanging with the locals, habits, culture, recipes, products etc. Based on written historical documents during the $19^{\text {th }}$ century, merchants from villages in the mountains of Pindos (such as Metsovo) were commercialized in Venice, Instanbul, Alexandria, Odessa, Vienna, Boudapest, selling products such as barrels, wool textiles and Kashkaval cheese (Pouqueville, 1820; Leake, 1835; Berard, 1911; Wace \& Thomson, 1914).

Mijacenic and Bulajic (2004) stated that Kashkaval cheese in the beginning was produced exclusively from sheep's milk during the grazing period, and nomads from Greece implemented the tradition of Kashkaval cheese on Stara Planina 100 years ago. Historical data showed that in the year 1903, 160 wagons of Kashkaval cheese were exported to Vienna and Budapest.

While in ancient times Kashkaval production was limited to the Greek and Roman empires as well as their colonies, nowadays it is produced in many parts of the world i.e. Crimea, South Ukraine, the Caucasus and Turkey, Greece, Italy, Bulgaria, Romania, Yugoslavia etc (Kindsted et al., 2004). In the Mediterranean region it is called simply Kashkaval with small differences in spelling. However, variations of that name can be found (Alichanidis \& Polychroniadou, 2008). Kashkaval has also been given different commercial names according to the production district such as Pirdop in Bulgaria, Epir in Greece, Sarplaninski and Pirotski Kaskaval in Yugoslavia (Pejic, 1956). The Italian version is Caciocavallo and in Egypt the name Romy is commonly used.

\section{Conclusions}

As there is an increasing demand of Kashkaval of Pindos cheese, it is important to study the effect of the different salting methods (dry salt or immersion in brine $18 \%$ or $15 \%$, w/w) which are commonly used by traditional cheese-makers. The results have shown that physicochemical characteristics of both cheeses were not affected by the different salting methods. Therefore, Kashkaval of Pindos cheese can be salted either with dry salt or with immersion in brine (15\% or $18 \%$ concentration). However more work must be done in order to find if there is an effect of these two different methods on its level of proteolysis, lipolysis and its microbiological data.

\section{Acknowledgments}

This research (MIS number: 5033162) was supported by the action "strengthening of small and medium-sized enterprises for research programs in the fields of agro-alimentary, health and biotechnology" and was co-financed by the European Union (European Regional Development Fund) and Greece, under the "Operational Program Epirus 2014-2020" of the National Strategic Reference Framework. The authors would like to thank Mrs V. Igoumenidou, Region of Epirus, for providing the historical data of Kashkaval of Pindos cheese.

\section{References}

Alichanidis, E., \& Polychroniadou, A. (2008). Characteristics of major traditional regional cheese varieties of East-Mediterranean countries: A review. Lait, 88, 410-495. https://doi.org/10.1051/dst:2008023 
Berard, V. (1911). La Turquie et l'hellénisme contemporain: La Macédoine: Hellènes. Bulgares. Valaques. Albanais. Autrichiens. Serbs. Ed by Alcan F, Paris.

Caric, M. (1993). Ripened cheese varieties native to the Balkan countries. In P. F. Fox (Ed.), (2nd ed., Vol. 2. Cheese: Chemistry, physics and microbiology (pp. 263-279). London, UK: Chapman \& Hall. https://doi.org/10.1007/978-1-4615-2648-3_9

Dimitriadis, R. (1900). About kefalotyri and kashkaval cheese. In G. Kasdonis (Ed.), Greek livestock (pp. 269-273). Athens, Greece: Bookshop of hearth (in Greek).

EEC. (1990). No $1225 / 90$ as regards the description of Kashkaval cheese. Official Journal of the European Communities, 33(L120), 56.

Gobbetti, M., Morea, M., Baruzzi, F., Corbo, M. R., Matarante, A., Considine, T., Cango, R. D., Guinee, T., \& Fox, P. F. (2002). Microbiological, compositional, biochemical and textural characterization of Caciocavallo Puliese cheese during ripening. Int. Dairy J., 12, 511-523. https://doi.org/10.1016/S0958-6946(02)00042-0

Greek Codex Alimentarius (2014). Official Journal of the Hellenic Republic. Vol B no 899 article 83 paragraph D3C. Athens: National Printing Office.

International Dairy Federation. (1982). Cheese and processed cheese. Determination of the total solids content. IDF Standard 4A. Brussels, Belgium: International Dairy Federation.

Kindstedt, P., Caric, M., \& Milanovic, S. (2004). Pasta-filata cheeses. In P. F. Fox, P. L. H. McSweeney, T. M. Cogan, \& T. P. Guinee (Eds.), 3rd ed., Major cheese groups: Cheese: Chemistry, physics and microbiology (pp. 251-277). London, UK: Elsevier Ltd. https://doi.org/10.1016/S1874-558X(04)80047-2

Kosikowski, F. V. (1982). Cheese and Fermented Milk Food. Edwards Brothers, Michigan.

Leake, W. M. (1835). Travels in Northern Greece. Ed by Rodwell J, London.

Liambeis, I. (1900). Kashkaval cheese. In M. I. Saliveros (Ed.), Milk making and cheese making (pp. 167-172). Athens, Greece (in Greek).

Mijacevic, Z., \& Bulajic, S. (2004). The traditional manufacturing of hard cheese-Kachkaval on Stara Planina mountain. Acta Agriculturae Slovenica, 84, 11-15.

Omar, M., \& El-Zayat, A. I. (1986). Ripening changes of Kashkaval cheese made from cow's milk. Food Chemistry, 22, 83-94. https://doi.org/10.1016/0308-8146(86)90027-0

Pappa, E. C., Kondyli, E., Bosnea, L., Mataragas, M., Giannouli, A., \& Tsiraki, M. (2020). Semi-industrial production of Kashkaval of Pindos cheese using sheep or mixture of sheep-goat milk and utilization of the whey for manufacturing Urda cheese. FOODS, 9, 736. https://doi.org/10.3390/foods9060736

Pappa, E. C, Kondyli, E., \& Samelis J. (2019). Microbiological and biochemical characteristics of Kashkaval cheese produced using pasteurized or raw milk. Int. Dairy J., 89, 60-67. https://doi.org/10.1016/j.idairyj.2018.08.011

Pappa, E. C., Kandarakis, I., Anifantakis, E. M., \& Zerfiridis, G. K. (2006). Influences of types of milk and culture on the manufacturing practices, composition and sensory characteristics of Teleme cheese during ripening. Food Control, 17, 570-581. https://doi.org/10.1016/j.foodcont.2005.03.004

Pejic, O. M. (1956). Dairy Technology. Technology of milk products, Naucna knjiga, Beograd, pp. 516.

Perna, A., Simonetti, A., Intaglietta, I., \& Gambacorta, E. (2014). Effects of genetic type, stage of lactation and ripening time on Caciocavallo cheese proteolysis. J. Dairy Sci, 97, 1909-1917. http://dx.doi.org/10.3168/jds.2013-7288

Polychroniadis, E. D. (1912). Kashkaval cheese. In the royal printing office. In N. Xioti (Ed.), Cheesemaking guide (pp. 95-103). Athens, Greece.

Pouqueville, F. H. L. (1820). Voyage dans la Grece. Chez Firmin Dido, Pere et Fils, Paris.

Samelis J., Kakouri, A, Kondyli, E., \& Pappa, E. C. (2019). Effects of curd heating with or without previous milk pasteurization on the microbiological quality and safety of craft-made 'pasta filata' Kashkaval cheese curds. Int. J. Dairy Technol., 72, 447-455. https://doi.org/10.1111/1471-0307.12601

Schneider, M. (1954). Traite pratique des assais du lait et du contrôle des produits laitieres. Berne, pp. 140.

Scintu, M. F., \& Piredda, G. (2007). Typicity and biodiversity of goat and sheep milk products. Small Rumin. Res., 68, 221-231. https://doi.org/10.1016/j.smallrumres.2006.09.005 
Scott, R. (1981). Cheese making practice. Elsevier Applied Science.

Wace, A. J. B., \& Thompson, M. S. (1914). The nomads of the Balkans, an account of life and customs among the Vlachs of Northern Pindus. Methuen \& co, Ltd, London.

\section{Copyrights}

Copyright for this article is retained by the author(s), with first publication rights granted to the journal.

This is an open-access article distributed under the terms and conditions of the Creative Commons Attribution license (http://creativecommons.org/licenses/by/4.0/). 